PRZEGLĄD NAUK HISTORYCZNYCH 2018, R. XVII, NR 2

http://dx.doi.org/10.18778/1644-857X.17.02.10

MichaËL Green

UnIWERSYTET KOPENHASKI*

\title{
Wpływ hugenotów na edukację niderlandzkiej szlachty ${ }^{1}$
}

$\mathrm{P}$ rezentowany artykuł ma na celu przedstawienie wyników badań, które dotyczą wpływu hugenotów na edukację niderlandzkiej szlachty. Podjałłem ten temat, ponieważ od drugiej połowy XVI w. do połowy wieku XVIII wielu francuskich kalwinistów, zwanych też hugenotami, przybywało do Republiki Zjednoczonych Prowincji bądź $z$ powodów ekonomicznych, bądź ze względu na prześladowania ze strony władz katolickich. Pierwsza fala mi-

* Duńskie Narodowe Centrum Badań nad Prywatnością / Danish National Research Foundation Centre for Privacy Studies, DNRF 138, e-mail: mgr@teol.ku.dk.

${ }^{1}$ Niniejszy artykuł jest nieznacznie zaktualizowanym tłumaczeniem innego tekstu, który ukazał się w języku rosyjskim: Gugienoty $i$ ich wkład $w$ wospitanije niderlandskogo dworianstwa, „Problemy socjalnoj istorii i kultury sriednich wiekow i ranniego nowogo wremienii” 2015, t. XII, s. 269-292. Artykuł opiera się na moich wcześniejszych publikacjach dotyczacych edukacji hugenockiej. Jego celem jest podsumowanie moich dotychczasowych badań, ze szczególnym uwzględnieniem edukacji w środowisku szlachty niderlandzkiej. M. Green, Bridging the English Channel: Huguenots in the Educational Milieu of the English Upper Class, „Paedagogica Historica” 2018, vol. LIV, No. 4, s. 389-409; i d e m, The Orange-Nassau family at the educational crossroads of the Stadholder's position (1628-1711), „Dutch Crossing: Journal of Low Countries Studies”, http://www.tandfonline. com/doi/full/10.1080/03096564.2016.1186925; i d e m, The Huguenot Jean Rou (1638-1711): Scholar, Educator, Civil Servant, Paris 2015; id e m, Huguenot Educators for European Nobility 1630-1715, „The Huguenot Society Journal” 2013, vol. XXX, No. 1, s. 73-92; ide m, Educating Johan Willem Friso of Nassau-Dietz (1687-1711): Huguenot Tutorship at the Court of the Frisian Stadtholders, „Virtus - Yearbook of The History of the Nobility" 2012, vol. XIX, s. 103-124; i d e m, The importance of Religion in the Educational Theory of Jean Rou, „Proceedings of the Huguenot Society of Great Britain and Ireland" 2010, vol. XXIX, No. 3, s. 408-417. 
gracyjna osiagnęła swój punkt kulminacyjny w 1572 r., tj. po nocy św. Bartłomieja. Badania przeprowadzone po 300 rocznicy unieważnienia edyktu nantejskiego (1685) wykazały, że ok. 50-120 tys. hugenotów opuściło Francję, by osiąść w innych europejskich krajach protestanckich. Druga fala migracyjna osiagnnęła $z$ kolei swoje apogeum w latach 1686-16872. Zjednoczone Prowincje były pierwszym przystankiem na drodze uciekających hugenotów, z których część migrowała następnie do Rzeszy Niemieckiej, Irlandii czy Anglii, a nawet dalej - do Ameryki Północnej.

Należy podkreślić, że migracja hugenotów nie była ,jednostkowym zdarzeniem", a długotrwałym procesem, który doprowadził do powstania hugenockich wspólnot poza Francją ${ }^{3}$. Zazwyczaj społeczności te skupiały się wokół kościoła (fr. temple). W Zjednoczonych Prowincjach imigranci $z$ pierwszej fali migracyjnej nazywani byli „Walonami”, gdyż znajdowało się wśród nich wielu mieszkańców belgijskiej Walonii. Ich kościoły określano więc mianem „kościołów walońskich" (fr. église wallone). W Anglii Edward VI pozwolił natomiast w 1550 r. na budowę tzw. kościołów reformowanych dla obcokrajowców. Powstało ich kilka w Londynie, a każdy miał swoich parafian ${ }^{4}$.

Kim byli migrujący hugenoci? Chociaż większość $z$ nich była w pewnym stopniu piśmienna ze względu na stawiany przez doktrynę kalwińską wymóg czytania Biblii, jedynie niewielki odsetek stanowili wśród nich ludzie wykształceni. Byli to rzemieślnicy, doktorzy, prawnicy, duchowni - zazwyczaj absolwenci hugenockich akademii, takich jak Puylaurens, Saumur, Sedan, Montauban,

${ }^{2}$ M. Yardeni, Le refuge protestant, Paris 1985; D. van der Linden, Experiencing Exile: Huguenot Refugees in the Dutch Republic, 1680-1700, Farnham 2015; M. Magdelain e, R. von Thadden, Le Refuge Huguenot, Paris 1985; R. Gwy n n, The Huguenots in Britain, the 'Protestant International' and the Defeat of Louis XIV, [w:] From Strangers to Citizens: The Integration of Immigrant Communities in Britain, Ireland, and Colonial America, 1550-1750, ed. R. Vigne, London 2001, s. 412-424.

${ }^{3}$ Więcej informacji na temat hugenotów w różnych krajach por. M. Yardeni, Le refuge Huguenot: Assimilation et culture, Paris 2002. Szczegółowo o hugenotach w Anglii: R. Gwynn, Huguenot Heritage: The History and Contribution of the Huguenots in Britain, $2^{\text {nd }}$ revised ed., London-New York 2001; id e m, The Huguenots of London, Brighton-Portland 1998. Na temat edukacji hugenockiej w Anglii por. M. Gree n, Bridging the English..., s. 389-409.

${ }^{4}$ H. Dunthorne, Britain and the Dutch Revolt 1560-1700, Cambridge 2013, s. 136. Por. także A. Pettegree, Foreign Protestant communities in sixteenth-century London, Oxford 1986; G.B. Beeman, Notes on the sites and history of the French Churches in London, London 1905. 
Namur, w których kształcono całe pokolenia wybitnych uczonych ${ }^{5}$. W przeciagu dwóch dekad od wydania edyktu nantejskiego (1598), który zapewniał hugenotom swobodę wyznania, otworzyło się wiele tego typu akademii ${ }^{6}$. Absolwentów tych uczelni poszukiwali zwłaszcza rodzice chcacy zatrudnić dobrze wykształconych nauczycieli do edukowania własnych dzieci.

Wpływ hugenotów na kulturę europejska jest niezwykle istotnym zagadnieniem, gdyż byli oni zatrudniani w różnych krajach protestanckich na terenie całego Starego Kontynentu. Jak się jednak okazuje, problematyka ta nie została dotychczas podjęta przez znanych badaczy tematu. Dowodem może być chociażby niedawno wydana książka pod redakcją Raymonda A. Mentzera i Bertranda Van Ruymbeke'a pt. A Companion to the Huguenots, ktora pomimo próby przedstawienia "wyczerpujaccego opisu hugenotów" nie poświęciła ani jednego ze swoich 20 rozdziałów na rozważania o hugenockich praktykach edukacyjnych ${ }^{7}$. Jednocześnie na przestrzeni ostatnich dziesięciu lat ukazały się tylko dwa opracowania zbiorowe, które poruszyły tematykę francuskojęzycznych szkół i nauczycieli w XVI-XIX w. Pierwsza $z$ książek wydana pod redakcja Geraldine Sheridan i Vivien Rosen-Prest, Les Huguenots éducateurs dans l'éspace europeén à l'époque moderne, była próba przedstawienia hugenockich nauczycieli i ich uczniów. Jednocześnie niektóre z zamieszczonych $\mathrm{w}$ niej artykułów poświęcone zostały tematyce edukacji szkolnej ${ }^{8}$. Biorac pod uwagę obszar geograficzny, badania koncentrowały się tu głównie na Świętym Cesarstwie Rzymskim, Irlandii i częściowo Anglii. Druga ze wspomnianych pozycji, wydana pod redakcja Vladislava Rjéoutskiego i Alexandre'a Tchoudinova (zarówno w wersji rosyjsko-, jak i francuskojęzycznej), to Le précepteur francophone en Europe, XVII ${ }^{-}-X I X^{e}$ siècles ${ }^{9}$. Pomimo rozległego

${ }^{5}$ W. Frijhoff, Uncertain Brotherhood, [w:] Memory and Identity: The Huguenots in France and the Atlantic Diaspora, eds B. van Ruymbeke, R.J. Sparks, Columbia 2003, s. 128-170, zwłaszcza 142.

${ }^{6}$ Akademia, jako instytucja szkolnictwa wyższego, jest odpowiednikiem uniwersytetu. K. Maag, The Huguenot Academies: Preparing for an Uncertain Future, [w:] Society and Culture of the Huguenot World 1559-1685, eds R.A. Mentzer, A. Spicer, Cambridge 2002, s. 139-156; M. Y ard e ni, Le refuge Huguenot..., s. 66-71.

7 A Companion to the Huguenots, eds R.A. Mentzer, B. van Ruymbeke, Leiden 2016. Cytat zaczerpnięto $z$ opisu dostarczonego przez wydawcę.

8 Les Huguenots éducateurs dans l'espace européen à l'époque moderne, eds G. Sheridan, V. Prest, Paris 2011.

${ }^{9}$ Le précepteur francophone en Europe, XVIIe-XIXe siècles, eds V. Rjéoutski, A. Tchoudinov, Paris 2013. 
zakresu badań, wyeksponowanego w tytule, większość artykułów poświęcona została historii francuskich nauczycieli w Rosji oraz w mniejszym stopniu w Anglii i w księstwach niemieckich. Mimo że obie książki przybliżyły czytelnikom zagadnienia związane $z$ dziejami hugenockich pedagogów, w żadnej $z$ nich nie przedstawiono sylwetek tych $z$ licznej grupy hugenotów, którzy nauczali w Zjednoczonych Prowincjach ${ }^{10}$. Ponadto autorzy poszczególnych rozdziałów tylko po części omówili opisywane zagadnienia, co uniemożliwiło im wyciągnięcie bardziej szczegółowych wniosków. Celem artykułu jest wypełnienie tej luki i zaznajomienie czytelnika zarówno $z$ kwestia hugenockich nauczycieli w Niderlandach, jak i ich związków z pracodawcami spośród niderlandzkiej szlachty.

Od wczesnych lat trzydziestych XVII w. do pierwszego dziesięciolecia wieku XVIII wielu hugenotów zatrudniano jako nauczycieli książąt Orańskich i hrabiów Nassau, stadhouderów różnych niderlandzkich prowincji. Wyjaśnijmy zatem najpierw, co oznacza pojęcie stadtholder. W swojej historii Zjednoczonych Prowincji Jonathan Israel stwierdza, że stanowisko to istniało już za czasów rządów hiszpańskich w poszczególnych prowincjach, a jego rola zbliżona była do tej, jaką odgrywał przedstawiciel króla. Głównym zadaniem stadhouderów była obrona terytorialna prowincji, jako że stali oni na czele wojska. Po wojnie o niepodległość Niderlandów pod koniec XVI w., w której jednym $z$ przywódców był Wilhelm I Orański, stadhouder prowincji Holandii, wszystkie stanowiska stadhouderów w Republice Zjednoczonych Prowincji zajmowane były przez przedstawicieli dynastii Orańskiej-Nassau - w Holandii przez gałąź Orańską $z$ centrum administracyjnym w Hadze, a we Fryzji przez książąt Nassau $z$ centrum administracyjnym w Leeuwarden. W hierarchii wojskowej stadhouder Fryzji podlegał stadhouderowi Holandii ${ }^{11}$. Stadhouder miał także bronić wyznania reformowanego. Według J.L. Price'a stadhouder był także niezwykle ważnym ogniwem spa-

${ }_{10}$ Ostatnia publikacja o podobnej tematyce z 2018 r. również pomija temat edukacji hugenockiej w Zjednoczonych Prowincjach i dotyczy głównie Rosji oraz w niewielkim stopniu Francji: Ideal of Noble Education in Europe: Seventeenth through Nineteenth Centuries [Idieal wospitanija dworianstwa w Jewropie: XVIIXIX wieka], eds V. Rjéoutski, I. Fediukin, W. Berelowitch, Moscow 2018.

11 J. Is rael, The Dutch Republic: Its Rise, Greatness, and Fall 1477-1806, Oxford 1995, s. 300-306, 486-487, 489-490, 537-539. Por. także poprawiona wersję z 2002 r. oraz H.H. Row en, The Princes of Orange: The Stadholders in the Dutch Republic, Cambridge 1988. Niderlandzkie słowo „stadhouder” pisane jest w jezzyku angielskim także jako „stadtholder” bądź „stadholder”. 
jającym niderlandzką społeczność ${ }^{12}$. Kiedy więc bezdzietny książę Orański Wilhelm III (1650-1702) wyznaczył na swojego następcę Jana Wilhelma Friso van Nassau-Dietz (1687-1711), ten ostatni zjednoczył w swoim ręku dobra i tradycje obu gałęzi rodu. Jak się przekonamy, przedstawiciele obu tych gałęzi, pomimo dzielących je różnic, w podobny sposób podchodzili do zagadnienia edukacji dzieci ${ }^{13}$.

W XVII w. powszechnie uważano, że dwór francuski powinien być wzorem dla możnowładców $z$ całej Europy. $Z$ tego powodu wśród arystokracji panowało przekonanie, że dzieci osób szlachetnie urodzonych powinny znać dworskie maniery oraz płynnie posługiwać się językiem francuskim ${ }^{14}$. Stał się on niezwykle ważny w pierwszej ćwierci XVII w. na haskim dworze księcia Fryderyka Henryka Orańskiego (1584-1647) ${ }^{15}$. Wtedy to stadhouder przestał być tylko i wyłącznie dowódca wojsk - stał się centralna postacią na dworze i pierwszym szlachcicem kraju, który powinien być otoczony ludźmi obeznanymi $z$ dworska etykieta ${ }^{16}$. Willem Frijhoff zauwa$\dot{z ̇ a}$, że już w 1608 r. opublikowano anonimowy wiersz, w którym autor narzekał na konieczność znajomości obcych obyczajów i języka francuskiego, gdyż każda niderlandzka córa marzy o szarmanckim „monsieur”" Według Frijhoffa do upowszechnienia języka francuskiego w wyższych sferach przyczyniły się nie tylko francuskie zwyczaje, ale także siła wpływu tzw. rzeczpospolitej uczonych (respublica litteraria), czyli nieoficjalnej, międzynarodowej społeczności uczonych ${ }^{18}$. Nie można też zapomnieć o roli, jaką odgrywał

12 J.L. Price, The Dutch Republic in the Seventeenth Century, Houndmills-London 1998, s. 21. Por. też W. Frijh off, M. Spies, 1650: Hard-Won Unity, Assen 2004.

${ }_{13}$ S. G ro enveld, Gemengde gevoelens. De relaties tussen Nassaus en Oranjes als stadhouders en kapiteins-generaal, [w:] Nassau uit de schaduw van Oranje, eds S. Groenveld, J.J. Huizinga, Y.B. Kuiper, Franeker 2003, s. 23-45.

${ }^{14}$ R.G. Asch, Nobilities in Transition 1550-1700: Courtiers and Rebels in Britain and Europe, London 2003; M. Motley, Becoming a French Aristocrat: The Education of the Court Nobility 1580-1715, Princeton 1990.

15 Podstawowe informacje na temat dynastii Orańskiej-Nassau w klasycznej pracy: N. Japikse, De Geschiedenis van het Huis van Oranje-Nassau, vol. I-II, Hague 1938.

${ }^{16}$ K.J. Riemens, Esquisse historique de l'enseignement du Français en Hollande du XVI $I^{e}$ au XIX $X^{e}$ siècle, Leiden 1919, s. 80.

17 W. Frijh off, Verfransing? Franse taal en Nederlandse cultuur tot in de revolutietujd, „Bijdragen en mededelingen betreffende de geschiedenis der Nederlanden" 1989, vol. CIV, s. 592-609, zwłaszcza 595.

18 W. Frijhoff, Des origines à 1780: l'émergence d'une image, „Histoire de la diffusion et de l'enseignement du français dans le monde", [b.m.] 1998, s. 8-20; 
język francuski w handlu i nauce. Znaczenie tego języka wzrosło jeszcze bardziej w połowie panowania Ludwika XIV (zasiadającego na tronie w latach 1643-1715), gdy francuski dwór stał się najważniejszym punktem spotkań europejskich elit i przyciagal zarówno szlachtę, jak i artystów, poetów czy uczonych. Warto też pamiętać, że Norbert Elias wykazał, iż król Francji utrzymał swój status dzięki przywilejom finansowym, których udzielał, i kontrolowaniu dostępu do swojej osoby, m.in. za pomoca etykiety ${ }^{19}$. I chociaż Zjednoczone Prowincje były republika, ksiażęce dwory w Hadze i Leeuwarden też były ważnymi ośrodkami kulturalno-politycznymi ${ }^{20}$.

\section{Podejście hugenotów do kwestii edukacji}

Opisana właśnie sytuacja wyższych sfer w XVII w. stanowi istotny kontekst dla zrozumienia wpływu hugenotów na edukację szlachty w Zjednoczonych Prowincjach. Najprawdopodobniej najważniejsza kwestia jest tutaj program nauczania, jaki hugenoci proponowali swoim arystokratycznym uczniom. Niestety, odpowiedź na tak postawione pytanie nie jest łatwa ze względu na brak odpowiednich źródeł. Istnieje jednak przynajmniej jedno źródło, które szczegółowo opisuje, jak powinien wyglądać program nauczania szlachetnie urodzonego dziecka.

Źródłem tym jest Projet pour l'éducation d'un jeune seigneur pióra Jeana Rou (1638-1711), hugenockiego uczonego, który napisał je około 1690-1691 r. dla przyszłego guwernera (fr. gouverneur) młodego Jana Wilhelma Friso, hrabiego Nassau ${ }^{21}$. Rou pochodził z paryskiej rodziny mieszczańskiej. Jego rodzicami byli Jacques Rou - prokurator (procureur) w paryskim parlamencie, i Isabelle Toutin pochodząca $z$ rodziny artystów. Po śmierci obojga rodziców (ojciec Jeana został zamordowany) Rou został 14-letnim sierota i dostał się pod opiekę wuja, który wysłał go na nauki do akademii w Saumur. Tam w 1659 r. uzyskał stopień magistra filozofii, a pół roku

idem, L'usage du français en Hollande, $X V I I^{e}-X I X^{e}$ siècles: propositions pour un modèle d'interprétations, „Etudes de linguistique appliquée” 1990, n 78, s. 17-26.

19 N. Elias, The Court Society, $2^{\text {nd }}$ ed., Oxford 2006.

20 O. Mörke, Sovereignty and Authority. The Role of the Court in the Netherlands in the First Half of the Seventeenth Century, [w:] Princes, Patronage, and the Nobility: The Court at the Beginning of the Modern Age c. 1450-1650, eds R.A. Asch, A.M. Birke, Oxford-New York-Toronto 1991, s. 455-477, zwłaszcza 463.

${ }^{21}$ Nie można ustalić tożsamości nauczyciela, którego Rou miał na myśli. Odnośnie do określenia tożsamości ucznia por. M. Green, The Huguenot..., rozdział 4. 
później zdał zwyczajowe egzaminy prawnicze. Przez kilka lat pracował jako prawnik w paryskim parlamencie, ale w niedługim czasie porzucił swoje stałe i dochodowe zajęcie na rzecz pisania. W kolejnych latach przetłumaczył kilka prac oraz napisał jedna własną: Tables de l'histoire universelle ancienne (1672), która zadedykowal francuskiemu Delfinowi. Cieszyła się ona niezwykła popularnościa i została zauważona przez samego Ludwika XIV ${ }^{22}$. Kontynuacja książki, napisana na zamówienie króla, który zlecił opisanie w niej współczesnej historii powszechnej, przyczyniła się jednak do rychłego załamania kariery Rou we Francji - publikacja znalazła się na liście prac zakazanych, a jej autora wtraccono do Bastylii, oskarżając go o nadużycie królewskich przywilejów i głoszenie antykatolickich poglądów. Po zwolnieniu $z$ więzienia, $z$ pomocą swojego patrona, księcia de Montausier, Rou został nauczycielem - na początku we Francji, później również w Anglii i Zjednoczonych Prowincjach, gdzie w 1689 r. został tłumaczem Stanów Generalnych. Zmarł w Hadze w 1711 r. $^{23}$ Wspomnienia, które Rou spisał pod koniec życia, sa nie tylko źródłem informacji na temat jego własnych losów, lecz także zawierają część korespondencji oraz wiele nieopublikowanych lub zaginionych utworów, autorstwa jego bądź jego przyjaciół. Dzieło to stanowi bardzo ważne źródło informacji na temat codziennego życia kulturalnego epoki. Wspomnienia te wydane zostały we Francji w 1857 r. przez Société pour l'histoire du Protestantisme Français pod redakcja Francisa Waddingtona ${ }^{24}$.

W Projet możemy przeczytać, co następuje: „Celem jest zapoznanie dziecięcia $z$ jego Stwórca, przyzwyczajenie do modlitw, do strachu przed Nim i do służenia Mu. Jest to pierwsza i podstawowa zasada dobrego wychowania, dzięki której nastapi postęp we wszystkich innych dziedzinach"25. Tezę tę uznać można za jego najważniejsza zasadę nauczania. Jest ona zgodna $z$ jedną $z$ zasad chrześcijańskiego humanizmu głoszonego przez Erazma $z$ Rotterdamu ${ }^{26}$. W swoim tekście Rou w mniejszym lub większym stopniu powoływał się też na

22 J. Rou, Tables de l'histoire universelle ancienne, Paris 1672; id e m, Tables de l'histoire universelle moderne, Paris 1675.

${ }^{23}$ Por. M. Green, The Huguenot..., rozdzial 1.

${ }^{24}$ J. Rou: Mémoires inédits et opuscules, ed. F. Waddington, vol. I-II, Paris 1857.

25 Ibidem, vol. I, s. 196. Wszystkie tłumaczenia zostały dokonane przez autora.

${ }^{26}$ Desiderius Eras mus, De pueris statim ac liberaliter instituendis, libellus et novus et elegans, Paris 1536. Por. także W.H. W o od wa rd, Desiderius Erasmus Concerning the Aim and Method of Education, Cambridge 1904. 
inne zasady Erazma. Dziecko powinno modlić się rano i wieczorem, by mieć stała świadomość boskiej obecności w swoim życiu. Rano powinno także odczytywać wybrane fragmenty z Biblii, których znaczenie powinno być objaśniane przez nauczyciela. Rou wyraźnie zaznaczył, że bojaźń Boża jest szczególnie ważna u kalwinistów, co wyraźnie widać na przykładzie Confession Belgica (które były w powszechnym użyciu w Zjednoczonych Prowincjach) oraz pamiętnikach Wilhelma Fryderyka van Nassau (1613-1664), dziadka Jana Wilhelma Friso ${ }^{27}$. Po obiedzie dziecko może natomiast przystąpić do nauk „świeckich” - historii, literatury, geografii, heraldyki. Zarówno dla Rou, jak i Erazma ważne było, by $z$ omawianego materiału wynikał jakiś morał, a nauczane przedmioty zazębiały się tematycznie ze sobą. W ten sposób historia mogłaby pomóc w nauce heraldyki, Biblia w kształtowaniu moralności i poznawaniu geografii, literatura w rozwoju własnej osobowości itp.

Mimo że Rou wyznawał erazmiańskie zasady humanizmu, w jego wizji nauczania nie brakowało także nowszych idei. Zakładał bowiem, że dziecko powinno „poznawać świat”, co stało co prawda w sprzeczności $z$ zasadami Erazma, ale ściśle wiązało się $z$ wizja angielskiego filozofa, Johna Locke’a, który spędził kilka lat w Zjednoczonych Prowincjach ${ }^{28}$. Tak jak Locke, Rou zalecal skupienie się na tych przedmiotach, które przydadzą się w prawdziwym życiu, a odradzał nauczanie dla samego nauczania. I tak np. łacina czy greka powinny być nauczane w zależności od potrzeb. Nigdy nie powinno się natomiast ich nadużywać $\mathrm{w}$ rozmowie. $\mathrm{W}$ tym punkcie Rou różni się w swoich poglądach od Locke’a, gdyż ten ostatni uważał, że znajomość greki nie jest potrzebna osobom szlachetnie urodzonym, a łacina może być użyteczna tylko osobom zainteresowanym nauka. Co ciekawe, w niezwykle popularnej i szeroko krytykowanej ksiażce pt. Dworzanin (Il libro del cortegiano) Baltassare Castiglione zauważa, że dworzanie powinni nie tylko znać dobrze łacinę, lecz także grekę, gdyż w obu tych językach opisano wiele interesujacych rzeczy ${ }^{29}$. Rou powtarzał także za Erazmem, że lekcje

27 Willem Frederik: Gloria parendi. Dagboeken van Willem Frederik, Stadhouder van Friesland, Groningen en Drenthe, 1643-1649, 1651-1654, eds J. Visser, G.N. van der Plaat, Hague 1995, s. 43, 112.

28 J.W. Yolton, John Locke and Education, New York 1971; P. Gay, John Locke on Education, New York 1971; S.J. Savonius-Wroth, The Educational Revolution of John Locke and his Huguenot allies, [w:] Les Huguenots éducateurs..., s. $155-186$.

${ }^{29}$ B. Castiglion e, Il libro del cortegiano, Venice 1528. 
powinny być prowadzone w sposób interesujaccy i że powinny one przypominać raczej zabawę niż ciężka pracę ${ }^{30}$.

\section{Osobista relacja ucznia z nauczycielem}

Największą różnicę między poglądami Rou i innych znanych pedagogów czasów nowożytnych widać w podejściu do kwestii relacji uczeń-nauczyciel. Według Rou aspekt ten ma duży związek z zagadnieniem prywatności, gdyż nauczyciele powinni traktować swoich uczniów jak braci. Inaczej stosunki te traktował Erazm, przyrównujac relację nauczyciela $z$ uczniem do więzi, jaka łączy ojca i syna. Jako że relacje braterskie sa $z$ reguły bardzo bliskie, Rou uważał, $\dot{z}$ e tego typu stosunek nauczyciela do ucznia umożliwi stworzenie czegoś, co można by nazwać prywatna strefa zaufania. Relacja jednostki $z$ samą soba, relacje $\mathrm{w}$ obrębie najbliższej rodziny, relacje w obrębie gospodarstwa domowego itp. - to różne tego typu kręgi czy sfery prywatności. Relacja nauczyciela $z$ uczniem, która chciał stworzyć Rou, charakteryzuje się zatem wysokim poziomem zaufania. W ten sposób Rou tworzy koncepcje czegoś, co można zdefiniować jako nowa strefe prywatności, która pod względem stopnia intymności sytuuje się zaraz po bardzo intymnej relacji dziecka z najbliższą rodziną ${ }^{31}$.

\section{Edukacja niderlandzkiej szlachty}

Po przeanalizowaniu hugenockiego traktatu naukowego możemy spróbować ustalić, w jakim stopniu koncepcje Rou spełniały oczekiwania rodziców i innych pedagogów. Po pierwsze, należy zaznaczyć, że najwybitniejszym i najbardziej znanym hugenockim pedagogiem w Zjednoczonych Prowincjach był teolog André Rivet (1572-1651), guwerner Wilhelma II (1626-1650), syna stadhoudera i księcia Orańskiego, Fryderyka Henryka (1584-1647) oraz Amalii van Solms (1602-1675). Jak zauważono wcześniej, para ta promowała język francuski na swoim książęcym dworze w Hadze,

${ }^{30}$ Desiderius Erasmus, op. cit.

${ }^{31}$ Więcej na temat prywatności por. M. Birkedal Bruun, Privacy in Early Modern Christianity and Beyond: Traces and Approaches, „Annali Instituto storico italo-germanico / Jahrbuch des italienisch-deutschen historischen Instituts in Trient" 2018, vol. XLIV, No. 2 [w druku]. Odnośnie do związu nauczyciel-uczeń i kwestii prywatności por. M. Green, L.C. Nøgaard, French Influence on Dutch Egodocuments: Privacy and the Orange-Nassau and Bentinck correspondences, 1632-1705 [złożone do druku]. 
gdzie zaproszono Riveta, dotychczasowego kierownika katedry teologii na uniwersytecie w Lejdzie, który miał zostać guwernerem ich syna $^{32}$. Samuel Chappuizeau (1625-1701), znany hugenocki uczony, był $z$ kolei guwernerem przyszłego stadhoudera Wilhelma III (1650-1702). Do innych znanych przykładów zaliczyć można takie postacie zwiąane $z$ trzema pokoleniami hrabiów van Nassau, jak Jean de Morel, guwerner Henryka Kazimierza II (1657-1696), Jean Lemonon, guwerner Jana Wilhelma Friso (1687-1711) (33 $^{3}$ czy pastor Isaac Lamigue, który był osobistym kaznodzieją Jana Wilhelma Friso i uczył jego syna, Wilhelma IV (1711-1751), francuskiego.

Głównym źródłem informacji o obowiązkach nakładanych na przyszłych nauczycieli sa ich kontrakty, w których znajdowały się wytyczne rodziców przyjmujących nowa osobę na to stanowisko. W 1632 r. Fryderyk Henryk napisal w umowie z Rivetem, że do zadań nauczyciela należy nauczenie Wilhelma II bojaźni Bożej, dobrych manier i skromności, a więc cnót, które miał on już z racji urodzenia. „wybierze metodę ćwiczeń [...], odpowiednia dla Wilhelma i będzie utrzymywał dyscyplinę konieczną do osiągnięcia tego celu, a także będzie mu przewodził i wszędzie towarzyszył, w razie potrzeby" ${ }^{34}$. Jak zatem widać, koncepcje wychowawcze Fryderyka Henryka pozostawały w zgodzie $z$ zasadami humanizmu chrześcijańskiego przedstawionymi w pracy Rou. Będąc małym dzieckiem, Wilhelm II napisał swoje motto, najprawdopodobniej pod czujnym okiem swojego guwernera Riveta: „Nic bez Boga” (fr. Rien sans Dieu), co dowodzi, że uczeń dobrze przyswoił sobie wpajany mu chrześcijański przekaz ${ }^{35}$.

Co więcej, obowiązek towarzyszenia uczniowi nałożony przez Fryderyka Henryka na guwernera zbliża nas ponownie do kwestii sfer prywatności. Fryderyk Henryk zadecydował bowiem, że Rivet stanie się częścią najbliższego kręgu ludzi skupionych wokół mło-

${ }^{32}$ H.H. Rowen, op. cit., s. 60. Informacje biograficzne oraz rola Riveta na dworze haskim por. A.G. Opstal, Andre Rivet: Een invloedrijk hugenoot aan het hof van Frederik Hendrik, Hardewijk 1937. Rivet zadedykował swojemu uczniowi książkę o nauczaniu, którą wydano po tym, jak skończył się jego angaż: Instruction du prince chrestien, Leiden 1642. Por. także L. Ko oijmans, Liefde in opdracht: Het hofleven van Willem Frederik van Nassau, Amsterdam 2000.

${ }^{33}$ Lemonon, Johannes, [w:] Frieslands Hoogeschool en het Rijks Athenaeum te Franeker, ed. W.B.S. Boeles, vol. II, Leeuwarden 1879, s. 329-330.

${ }^{34}$ Commission from Frederik Hendrik to André Rivet, 12 II 1632, Royal House Archives [dalej: RHA], MS. A15-V-1.

${ }^{35}$ Rien sans Dieu, 1637, RHA, A15-XII-3-9. 
dego księcia, osobą szczególnie zaufaną, wtajemniczoną we wszystkie sprawy dziecka. W ten oto sposób słowa ojca popierają ideę umiejscowienia guwernera w strefie prywatności, która plasuje się tuż za najbardziej intymną strefą dziecka i jego rodziców.

Podobne koncepcje możemy odnaleźć w angażu Fryderyka van Nassau van Zuylestein (1624-1672), nieślubnego syna Fryderyka Henryka, a więc stryja i guwernera Wilhelma III ${ }^{36}$. Według matki Wilhelma, Mary Stuart, wdowy po Wilhelmie II, i jego babki, Amalii van Solms, guwerner miał edukować młodego księcia zgodnie $z$ tradycja wyznania reformowanego. Miał on nauczyć go cnoty i dobrych manier, łaciny i innych przedmiotów, jak i towarzyszyć we wszystkim. Ponownie więc guwerner znalazł się w trzeciej sferze prywatności, czyli po sferze ściśle indywidualnej i rodzinnej. W tym miejscu warto zauważyć, że do nauczania Wilhelma III zatrudniono również dwóch innych hugenotów. Byli to Samuel Chappuizeau, który uczył młodego księcia języka francuskiego, oraz malarz Abraham Raguineau, który nauczał go czytania, pisania, rysowania i rachowania.

Jak już wspomnieliśmy, edukacja religijna odgrywała istotna rolę, ponieważ stadhouder miał być obrońca kalwinizmu ${ }^{37}$. Oczywiście podkreślanie znaczenia religii było charakterystyczne nie tylko dla Niderlandzkiego Kościoła Reformowanego. Przykładowo, młody Anglik, Philip Perceval, odbył Grand Tour po Francji, gdzie, jak wynika $z$ listu jego hugenockiego nauczyciela, Alexandre'a de Rasigade'a, uczestniczył w synodzie w Saumur i słuchał religijnych dysput, prowadzonych przez takich kalwińskich teologów jak Etienne de Bray ${ }^{38}$.

Co ciekawe, poświęcanie zbyt wiele czasu na edukację religijną nie zawsze było dobrze postrzegane przez rodziców. Jean Rou opisał w swoich wspomnieniach sytuację z 1680 r., gdy będąc guwernerem synów Cornelisa van Aerssen van Sommelsdijka (zwolennika Wilhelma III) i hugenockiej szlachcianki, Marguerite du Puys de Saint André, wdał się w konflikt $z$ tą ostatnią. Mimo że dała się poznać Rou jako osoba zainteresowana religia, zapraszajac go do wspólnego słuchania różnego rodzaju kazań, stwierdziła, że poświęca on zbyt dużo czasu na religię kosztem pozostałych przedmiotów. Pierre

${ }^{36}$ Commision pour le Sr. De Suylesteyn comme gouverneur de son Altesse, 27 IX 1659, RHA, MS. B12-27.

${ }^{37}$ J. Is rae1, op. cit., s. 305.

38 Alexandre de Rasigade do Roberta Southwella, Saumur 3/13 XI 1677, British Library, Add MS 46954 B, f. 201-202. 
Jurieu, słynny teolog i bliski znajomy Jeana Rou, starał się pomóc w rozstrzygnięciu sporu, jednak bezskutecznie: Rou został zwolniony z posady i przez pewien czas poświęcił się karierze administracyjnej.

O ile niderlandzkie rodziny zatrudniały hugenockich pedagogów w nadziei, że ci nauczą ich dzieci dworskich manier, o tyle niewielu $z$ nich miało tak naprawdę pojęcie o tym, jak funkcjonuje francuski dwór. André Rivet był we Francji pastorem w domu księcia de Le Trémouille i jego żony do roku 1620, gdy został profesorem na uniwersytecie w Lejdzie ${ }^{39}$. Jean Rou również miał styczność z dworskim życiem, dopóki nie zakazano jego Tables de l'histoire moderne (1675). Stąd wniosek, że jeśli niderlandzkie rodziny nie były w stanie znaleźć nauczyciela obeznanego $z$ dworską etykieta, zatrudniały Francuzów zaznajomionych przynajmniej z kultura swojej ojczyzny. Warto jednak zauważyć, że nie wszyscy mieszkańcy Zjednoczonych Prowincji byli miłośnikami kultury francuskiej. Przykładowo, Jean de Morel został skrytykowany przez Johana Mauritsa, wuja Henryka Kazimierza II, za bycie „zbyt francuskim” jak na godnego do naśladowania niderlandzkiego szlachcica ${ }^{40}$.

Warto wreszcie zauważyć, że poza językiem francuskim, religia i dworskimi manierami, młodzi arystokraci nauczani przez hugenotów mieli też w swoim programie tzw. studia humanitatis. Zgodnie z głoszoną przez Erazma zasadą łączenia różnych przedmiotów, Wilhelm II czytał De bello Gallico Cezara ${ }^{41}$. Rou natomiast zwykł czytać ze swoimi uczniami bajki, aby uczyć ich zarówno moralności, jak i literatury ${ }^{42}$. W tym sensie wszystkie istotne elementy edukacji humanistycznej były obecne w nauczaniu hugenotów.

\section{Podsumowanie}

Wyraźnie widać, że wpływ humanizmu chrześcijańskiego na hugenockich nauczycieli był bardzo istotny zarówno $\mathrm{w}$ ich praktyce dydaktycznej, jak i w pisanych przez nich pracach teoretycznych

${ }^{39}$ Rivet, [w:] Eug. Haag, Em. Haag, La France protestante ou vies des Protestants Français qui se sont fait un nom dans l'histoire depuis les premiers temps de la Reformation jusqu'à la reconnaissance de principe de la liberté des cultes par l'Assemblée Nationale, vol. I-X, Paris 1846-1859, tutaj vol. VIII, s. 444.

${ }^{40}$ Johan Maurits do Albertine'a Agnesa, 15 IX 1673, za: J.W. van Sype steyn, Geschiedkundige bijdragen, bijlagen, IX, Hague 1865.

${ }^{41}$ Wilhelm II do Fryderyka Henryka Orańskiego, [b.m.] VIII 1639, Ick ben bedroeft..., RHA, MS A-14-XI-A-16.

${ }^{42}$ J. Rou: Mémoires..., vol. I, s. 198. 
poświęconych tej tematyce. Ich popularność jako guwernerów można wyjaśnić po pierwsze, znaczną liczebnością społeczności hugenotów w krajach protestanckich, a po drugie, upowszechnieniem francuskiego języka, dworskich manier i kultury wśród szlachty. Jak widać na przykładzie szlachty niderlandzkiej, utrzymywanie przynajmniej jednego hugenockiego nauczyciela w rodzinie było niemalże czymś oczywistym.

Ponieważ tendencja do zatrudniania hugenotów jako guwernerów w rodzinach arystokratycznych utrzymywała się dość długo (od końca XVI do początku XVIII w.), można ich postrzegać jako swojego rodzaju pośredników między własna kultura a kultura krajów, w których pracowali. Jak wykazałem w moich wcześniejszych pracach poświęconych zagadnieniu hugenockich nauczycieli w innych krajach, dysponowali oni umiejętnościami i charakteryzowali się cechami, które w takim zestawieniu były czymś wówczas niespotykanym w żadnej innej grupie społecznej ${ }^{43}$.

Z języka angielskiego przełożyła

AlEKSANDRA BARTOSIEWICZ

UNIWERSYTET ŁÓDZKI*

\section{Bibliografia}

\section{$\dot{Z}_{\text {RÓdea ARCHIWALNE }}$}

Royal House Archives, Haga [RHA]

Commision pour le Sr. De Suylesteyn comme gouverneur de son Altesse, 27 IX 1659, MS. B12-27.

Commission from Frederik Hendrik to André Rivet, 12 II 1632, MS. A15-V-1.

Rien sans Dieu, 1637, MS. A15-XII-3-9.

Wilhelm II do Fryderyka Henryka Orańskiego, [b.m.] VIII 1639, Ick ben bedroeft..., MS A-14-XI-A-16.

British Library, Londyn

Alexandre de Rasigade do Roberta Southwella, Saumur 3/13 XI 1677, Add MS 46954 B, f. 201-202.

** Wydział Ekonomiczno-Socjologiczny, Instytut Ekonomik Stosowanych i Informatyki, Katedra Badań Operacyjnych, e-mail: aleksandra.bartosiewicz@uni.lodz.pl.

43 Obecnie autor pracuje nad książka na temat edukacji hugenockiej. 


\section{$\dot{Z}_{\text {RÓDEA DRUKOWANE }}$}

Castiglione B., Il libro del cortegiano, Venice 1528.

Erasmus Desiderius, De pueris statim ac liberaliter instituendis, libellus et novus et elegans, Paris 1536.

J. Rou: Mémoires inédits et opuscules, ed. F. Waddington, vol. I-II, Paris 1857.

Rivet A., Instruction du prince chrestien, Leiden 1642.

Rou J., Tables de l'histoire universelle ancienne, Paris 1672.

Rou J., Tables de l'histoire universelle moderne, Paris 1675.

Willem Frederik: Gloria parendi. Dagboeken van Willem Frederik, Stadhouder van Friesland, Groningen en Drenthe, 1643-1649, 1651-1654, eds J. Visser, G.N. van der Plaat, Hague 1995.

\section{Opracowania}

A Companion to the Huguenots, eds R.A. Mentzer, B. Van Ruymbeke, Leiden 2016. Asch R.G., Nobilities in Transition 1550-1700: Courtiers and Rebels in Britain and Europe, London 2003.

Beeman G.B., Notes on the sites and history of the French Churches in London, London 1905.

Birkedal Bruun M., Privacy in Early Modern Christianity and Beyond: Traces and Approaches, „Annali Instituto storico italo-germanico / Jahrbuch des italienisch-deutschen historischen Instituts in Trient” 2018, vol. XLIV, No. 2 [w druku].

Dunthorne H., Britain and the Dutch Revolt 1560-1700, Cambridge 2013.

Elias N., The Court Society, $2^{\text {nd }}$ ed., Oxford 2006.

Frieslands Hoogeschool en het Rijks Athenaeum te Franeker, ed. W.B.S. Boeles, vol. I-II, Leeuwarden 1879.

Frijhoff W., Des origines à 1780: l'émergence d'une image, „Histoire de la diffusion et de l'enseignement du français dans le monde" 1998, s. 8-20.

Frijhoff W., L'usage du français en Hollande, XVII -XIXe siècles: propositions pour un modèle d'interprétations, „Etudes de linguistique appliquée” 1990, n 78 , s. $17-26$.

Frijhoff W., Uncertain Brotherhood, [w:] Memory and Identity: The Huguenots in France and the Atlantic Diaspora, eds B. Van Ruymbeke, R.J. Sparks, Columbia 2003, s. 128-170.

Frijhoff W., Verfransing? Franse taal en Nederlandse cultuur tot in de revolutietu$j d$, „Bijdragen en mededelingen betreffende de geschiedenis der Nederlanden” 1989, vol. CIV, s. 592-609.

Frijhoff W., Spies M., 1650: Hard-Won Unity, Assen 2004.

Gay P., John Locke on Education, New York 1971.

Green M., Bridging the English Channel: Huguenots in the Educational Milieu of the English Upper Class, „Paedagogica Historica” 2018, vol. LIV, No. 4, s. 389-409. 
Green M., Educating Johan Willem Friso of Nassau-Dietz (1687-1711): Huguenot Tutorship at the Court of the Frisian Stadtholders, "Virtus - Yearbook of The History of the Nobility" 2012, vol. XIX, s. 103-124.

Green M., Gugienoty i ich wkład w wospitanije niderlandskogo dworianstwa, „Problemy socjalnoj istorii i kultury sriednich wiekow i ranniego nowogo wremienii" 2015, t. XII, s. 269-292.

Green M., Huguenot Educators for European Nobility 1630-1715, „The Huguenot Society Journal" 2013, vol. XXX, No. 1, s. 73-92.

Green M., The Huguenot Jean Rou (1638-1711): Scholar, Educator, Civil Servant, Paris 2015.

Green M., The importance of Religion in the Educational Theory of Jean Rou, „Proceedings of the Huguenot Society of Great Britain and Ireland" 2010, vol. XXIX, No. 3, s. 408-417.

Green M., Nøgaard L.C., French Influence on Dutch Egodocuments: Privacy and the Orange-Nassau and Bentinck correspondences, 1632-1705 [złożone do druku].

Groenveld D., Gemengde gevoelens. De relaties tussen Nassaus en Oranjes als stadhouders en kapiteins-generaal, [w:] Nassau uit de schaduw van Oranje, eds S. Groenveld, J.J. Huizinga, Y.B. Kuiper, Franeker 2003, s. 23-45.

Gwynn R., Huguenot Heritage: The History and Contribution of the Huguenots in Britain, $2^{\text {nd }}$ revised ed., London-New York 2001.

Gwynn R., The Huguenots in Britain, the 'Protestant International' and the Defeat of Louis XIV, [w:] From Strangers to Citizens: The Integration of Immigrant Communities in Britain, Ireland, and Colonial America, 1550-1750, ed. R. Vigne, London 2001, s. 412-424.

Gwynn R., The Huguenots of London, Brighton-Portland 1998.

Haag Eug., Haag Em., La France protestante ou vies des Protestants Français qui se sont fait un nom dans l'histoire depuis les premiers temps de la Reformation jusqu'à la reconnaissance de principe de la liberté des cultes par l'Assemblée Nationale, vol. I-X, Paris 1846-1859.

Ideal of Noble Education in Europe: Seventeenth through Nineteenth Centuries [Idieat wospitanija dworianstwa w Jewropie: XVII-XIX wieka], eds V. Rjéoutski, I. Fediukin, W. Berelowitch, Moscow 2018.

Israel J., The Dutch Republic: Its Rise, Greatness, and Fall 1477-1806, Oxford 2002.

Japikse N., De Geschiedenis van het Huis van Oranje-Nassau, vol. I-II, Hague 1938.

Kooijmans L., Liefde in opdracht: Het hofleven van Willem Frederik van Nassau, Amsterdam 2000.

Le précepteur francophone en Europe, XVII -XIX ${ }^{e}$ siècles, eds V. Rjéoutski, A. Tchoudinov, Paris 2013.

Les Huguenots éducateurs dans l'espace européen à l'époque moderne, eds G. Sheridan, V. Prest, Paris 2011. 
Maag K., The Huguenot Academies: Preparing for an Uncertain Future, [w:] Society and Culture of the Huguenot World 1559-1685, eds R.A. Mentzer, A. Spicer, Cambridge 2002, s. 139-156.

Magdelaine M., Von Thadden R., Le Refuge Huguenot, Paris 1985.

Mörke O., Sovereignty and Authority. The Role of the Court in the Netherlands in the First Half of the Seventeenth Century, [w:] Princes, Patronage, and the Nobility: The Court at the Beginning of the Modern Age c. 1450-1650, eds R.A. Asch, A.M. Birke, Oxford-New York-Toronto 1991, s. 455-477.

Motley M., Becoming a French Aristocrat: The Education of the Court Nobility 1580 1715, Princeton 2016.

Opstal A.G., Andre Rivet: Een invloedrijk hugenoot aan het hof van Frederik Hendrik, Hardewijk 1937.

Pettegree A., Foreign Protestant communities in sixteenth-century London, Oxford 1986.

Price J.L., The Dutch Republic in the Seventeenth Century, Houndmills-London 1998.

Riemens K.J., Esquisse historique de l'enseignement du Français en Hollande du XVI ${ }^{e}$ au XIX $X^{e}$ siècle, Leiden 1919.

Rowen H.H., The Princes of Orange: The Stadholders in the Dutch Republic, Cambridge 1988.

Van der Linden D., Experiencing Exile: Huguenot Refugees in the Dutch Republic, 1680-1700, Farnham 2015.

Van Sypesteyn J.W., Geschiedkundige bijdragen, bijlagen, IX, Hague 1865.

Woodward W.H., Desiderius Erasmus Concerning the Aim and Method of Education, Cambridge 1904.

Yardeni M., Le refuge Huguenot: Assimilation et culture, Paris 2002.

Yardeni M., Le refuge protestant, Paris 1985.

Yolton J.W., John Locke and Education, New York 1971.

\section{Netografia}

Green M., The Orange-Nassau family at the educational crossroads of the Stadholder's position (1628-1711), „Dutch Crossing: Journal of Low Countries Studies” 2016, http://www.tandfonline.com/doi/full/10.1080/03096564. 2016.1186925. 